\title{
Challenges and Alternatives in Dental Education During the COVID-19 pandemic. Integrative Literature Review*
}

Desafíos y alternativas en la educación dental durante la pandemia del COVID-19.

Revisión integrativa de la literatura

Desafíos e alternativas na educação odontológica durante a pandemia COVID-19. Revisão integrativa da literatura

Submission date: 23-06-2020 | Acceptance date: 17-12-2020

Francisco Cazares de León

Universidad de Monterrey. Monterrey, México. fclsalud@ gmail.com; http://orcid.org/0000-0002$\underline{0481-8956}$

María de Lourdes Juanita Cantú Canales

Universidad Autónoma de Nuevo León. Monterrey, México. m.lourdescantu96@gmail.com; https://orcid.org/0000-0003-2427-966X

Víctor RAFael Rodríguez Castillo

Universidad Americana, Escuela de Odontología, Nicaragua. vrrodriguez@uamv.edu.ni;

https://orcid.org/0000-0003-4717-1715 


\section{Pedro GutiérRez Lizardi (in memoriam)}

Universidad de Monterrey. Monterrey, México.drglizardi@hotmail.com;

https://orcid.org/0000-0002-7723-6498

\section{DAVID ERNESTo Soto GÁMEZ}

Universidad Autónoma de Nuevo León. Monterrey, México. david.soto@saludnl.gob.mx;

https://orcid.org/0000-0001-8669-6632

\section{María Gabriela Peraldi Sada}

Universidad Nacional Autónoma de Nicaragua León. León, Nicaragua. ljespinozah@yahoo.com;

https://orcid.org/0000-0002-4696-2403

Correspondencia: fclsalud@gmail.com; m.lourdescantu96@gmail.com;

vrrodriguez@uamv.edu.ni; drglizardi@hotmail.com; david.soto@saludnl.gob.mx;

jespinozah@yahoo.com

* Original documental research. Integrativa literatura review.

doi: https://doi.org/10.11144/Javeriana.uo39.cade

How to cite: Cazares de León F, Cantú Canales M, Rodríguez Castillo VR, Gutiérrez Lizardi P, Soto Gámez DE, Peraldi Sada MG. Challenges and Alternatives in Dental Education During the 
COVID-19 pandemic. Integrative Literature Review. Univ Odontol. 2020; 39. https://doi.org/10.11144/Javeriana.uo39.cade

\section{ABSTRACT}

Background: The current COVID-19 pandemic has become a major health challenge and a public health emergency, so it is important to strengthen preventive measures to control its spread. The transmissibility and routes that characterize this virus make it very high risk during dental procedures. For this reason, different organizations and institutions of dental education worldwide have been forced to implement new teaching modalities for dental students to provide a high academic and safe education in clinical practice. Purpose: To examine and analyze different existing publications in relation to dental education, as well as its challenges and alternatives around the COVID-19 disease. Methods: An integrative review of literature on dental education in times of pandemic was carried out. Results: In all continents, countries agree that three key aspects in terms of education must be reinforced are new educational tools, telemedicine, and biosecurity. Conclusion: It is decisive and crucial that dental students and professionals acquire knowledge in matters of health regulations, biosafety, and general aspects of epidemiology, through new forms of teaching, in order to be better prepared to provide the best possible dental care during and after this pandemic.

\section{Keywords}

biosecurity; COVID-19; dental education; dental schools; dentistry; educational technology; normativity; pandemic; public health; teaching strategies; telemedicine 


\section{RESUMEN}

Antecedentes: La actual pandemia del COVID-19 se ha convertido en un gran desafío para la salud y una emergencia de salud pública, por lo que es importante reforzar las medidas preventivas para controlar su propagación. La transmisibilidad y rutas que caracterizan a este virus, lo hacen de muy alto riesgo durante los procedimientos odontológicos. Por esto, distintos organismos e instituciones de educación odontológica mundialmente se han visto forzados a implementar nuevas modalidades de enseñanza a los estudiantes de odontología para brindar una educación de alto nivel académico y segura en la práctica clínica. Objetivo: Examinar y analizar distintas publicaciones existentes en relación con la educación odontológica, así como sus desafíos y alternativas entorno a la enfermedad del COVID-19. Métodos: Se realizó una revisión integrativa de la literatura sobre la educación en odontología en tiempos de pandemia. Resultados: En todos los continentes, los países coinciden en que se tienen que reforzar tres aspectos clave en términos de educación: nuevas herramientas educativas, telemedicina y bioseguridad. Conclusión: Es determinante y clave que los estudiantes y profesionales de la salud bucal adquieran conocimientos en materia de normatividad sanitaria, bioseguridad y aspectos generales de epidemiología, a través de nuevas formas de enseñanza con el fin de estar mejor preparados para brindar la mejor atención posible en la práctica odontológica durante y después de esta pandemia.

\section{Palabras clave}


bioseguridad; COVID-19; educación odontológica; escuelas de odontología; estrategias de enseñanza; facultades de odontología; normatividad; odontología; pandemia; salud pública; tecnología educativa; telemedicina

\section{RESUMO}

Antecedentes: A atual pandemia de COVID-19 tornou-se um grande desafio para a saúde e uma emergência de saúde pública, por isso é importante fortalecer as medidas preventivas para controlar sua propagação. A transmissibilidade e as rotas que caracterizam esse vírus tornam-no de altíssimo risco durante procedimentos odontológicos. Por este motivo, diferentes organizações e instituições de ensino odontológico em todo o mundo têm sido forçados a implementar novas modalidades de ensino para estudantes de odontologia para fornecer uma formação acadêmica elevada e segura na prática clínica. Objetivo: Examinar e analisar as diferentes publicações existentes em relação à educação odontológica, bem como seus desafios e alternativas em torno da doença COVID-19. Métodos: Foi realizada uma revisão integrativa da literatura sobre educação odontológica em tempos de pandemia. Resultados: em todos os continentes, os países concordam que três aspectos fundamentais em termos de educação devem ser reforçados: novas ferramentas educacionais, telemedicina e biossegurança. Conclusão: É decisivo e fundamental que estudantes e profissionais de saúde bucal adquiram conhecimentos em matéria de regulação sanitária, biossegurança e aspectos gerais da epidemiologia, por meio de novas formas de ensino a fim de estarem melhor preparados para prestar o melhor cuidado possível na prática odontológica durante e após esta pandemia. 


\section{Palavras chave}

biossegurança; COVID-19; educação odontológica; escolas de odontologia; estratégias de ensino; facultades de odontologia; normatividade; odontologia; pandemia; saúde pública; tecnologia educativa; telemedicina

\section{INTRODUCTION}

COVID-19 (SARS-CoV-2) emerged in the city of Wuhan, China, at the end of December 2019. From this date, a global spread was triggered. On March 11, 2020, the World Health Organization (WHO) declared this virus a pandemic that has become a public health emergency and a major health challenge. Due to its alarming levels of spread and severity, it is very important to reinforce preventive measures to control its spread (1-3).

The SARS-CoV-2 virus enters the cell in the same way as the Severe Acute Respiratory Syndrome (SARS) coronavirus, via the ACE 225 receptor. SARS-CoV-2 uses the ACE2 receptor to enter cells, thereby promoting person-to-person transmission. These cells have been found to be abundant in the respiratory tract and salivary glands of the mouth $(3,4)$. The transmission routes of the coronavirus are direct and by contact; in the first case it occurs through sneezing, coughing (saliva) and Flügge droplets (small or thick saliva and mucus); in the second case they occur through the nasal, oral, and ocular mucous membranes. The incubation period is considered to be 0-24 days $(1,3,5)$. Therefore, dental school/college clinics are high-risk areas for the transmission of SARS-CoV-2 among patients, students, and instructors (6). 
The WHO has promoted precautionary measures to try to control the COVID-19 pandemic, as it has significantly affected the educational, economic, and social environment $(3,7-9,10-15)$. It is known that dental education and practice are affected and interrupted when there is a crisis such as a pandemic, epidemic, war, or political unrest. This COVID-19 pandemic has once again affected education and health care $(11,12)$. Online teaching strategies have been in place for a long time, when teledentistry was introduced in 1994 as part of a military project to improve patient care and dental education for the United States Army.

Regarding dental education, a study conducted at the University of Otago, New Zealand, determined that a high number of dental staff and students in $90 \%$ and $93 \%$ respectively, perceived that their health was at risk while working in dental clinics during the COVID-19 pandemic. This also increased the degree of stress to $80 \%$ among staff and $87 \%$ in students (13). On the other hand, at the University of Utah in the United States, $72 \%$ of undergraduate dental students reported having previously taken an online course, so the transition from the classroom to virtual teaching model was not difficult for them. $87.6 \%$ reported a high degree of compliance to adapt to the technology. It should be noted that no student felt uncomfortable. However, $38 \%$ were concerned about the quality of the content of online courses (14).

In this new reality, dental schools have different challenges to meet the goal of redesigning their curricula for their clinical, face-to-face, and online teaching, without neglecting the safety of students, teaching staff, and patients. A concomitant challenge is adjusting academic calendars while maintaining academic standards, research, and clinical activities $(15,16)$. Likewise, 
educational institutions face the challenge of reorganizing their infrastructure and teaching methods to be able to face the possible consequences of this new reality, always taking care of and promoting the continuous advancement of future dentists (16). Given this, some countries have proposed updating preventive dentistry courses, more continuing education, and workshops to improve infection control within teaching clinics $(15,17)$.

The purpose of this study was to review relevant literature that allows identifying the challenges in dental education in topics such as clinical practice, biosafety measures, and instruction, as well as its challenges and alternatives around the COVID-19 disease.

\section{MATERIALS AND METHODS}

The type of study was an integrative review of the literature on dental education in times of pandemic. The criteria established by Whittemore et al. 2014 to conduct integrative reviews were followed (18). The review focused on COVID-19 and the educational tools that have emerged in dental schools/colleges in different countries on all continents, as well as the biosafety protocols implemented.

Articles that met the following inclusion criteria were selected: 1) focus on the education of dental schools/colleges in their different undergraduate (predoctoral) and graduate specialties (postdoctoral) in the world; 2) articles published in 2020; 3) publications in English and Spanish; 4) official reports from secretaries of health, ministries of health, or international organizations; and 5) publications made exclusively in the university environment. 
As exclusion criteria, the following were taken into account: 1) articles outside the educational dental institutions; 2) opinion pieces by a single author or editor; and 3) articles focused on professional dental practice.

\section{Procedure}

A search of articles was carried out in the bibliographic services databases: Web of Science, SciELO, and Google Scholar. The following word combinations were searched: "COVID-19" AND “dental;" "pandemic" AND “dental;" and "dental Education” AND "COVID-19” AND "pandemic." In addition, information was sought from theoretical articles in relation to similar topics and the experiential knowledge of two of the authors was used.

\section{RESULTS}

\section{Educational tools}

The pandemic has had an immediate and dramatic impact on dental education, as institutions face the challenge of reorganizing their infrastructure and teaching strategies $(19,20)$. To increase the safety of students and staff, digital platforms, webinars, exams, and online conferences, among other things, were used to prevent their exposure to the virus. This situation and the teaching-learning means can stress and distress professors and students $(10,19)$.

Although COVID-19 is generally perceived as something negative, it can be recognized that it has helped new educational modalities gain relevance (20). Online teaching has played an important 
role in the provision of education and has been a well-accepted strategy for higher education in the world. This type of teaching could improve time management, communication skills, critical thinking, and knowledge. It could be applied beyond the physical limits of the classroom (21).

The education sector was one of the first to suffer the effects of the pandemic due to the implementation of social distancing measures as a way to prevent the collapse of health systems (22). For example, following WHO guidelines, most of Brazil's mayors and governors suspended face-to-face classes in educational institutions, among other measures, with the aim of creating isolation and reducing the spread of the virus (20). One must be attentive to the indications issued by the health authorities when it is possible to return to normality $(10,19)$.

Faced with the COVID-19 epidemic, the work of educators has been challenged to create new teaching models that promote student creativity beyond the traditional teacher-centered teaching model (23). University institutions and professors have been forced to transform the methods and contents of teaching in the classroom through systematic training and technical support. Student learning attitudes and motivations are also essential factors for the success of online teaching $(23,24)$. A study carried out in France, through surveys of dental students at the University of Montpellier, showed that the most widely used visual resources on the internet were videos of clinical demonstrations carried out on patients in real life. The researchers of that study aimed to identify the pedagogical support that students preferred according to their discipline. They concluded that all students requested videos for clinical topics such as endodontics (23). At the University of Texas at Houston, the WebEx® ${ }^{\circledR}$ digital platform was used to conduct emergency medical dental classes and demonstrations. The students showed a positive response; however, 
they declared that they prefer face-to-face classes to carry out their practices on mannequins themselves (24). In another study carried out at the University of Costa Rica, it was found that the dental students surveyed had access to the Internet; nevertheless, the quality and stability of the connection differed between varying devices. All students had access to a virtual environment using a laptop (84\%), a cell phone (64\%), a tablet (39\%), or a desktop computer (8\%) (23).

As part of the curriculum in dentistry, prior to caring for patients in the clinic, students carry out practices in simulators. However, gathering all the students around a dental simulator in the middle of a pandemic can be difficult due to the difficulty of keeping their distance. At the University of Sydney in Australia, students were asked to carry out these practices at home with a micromotor, while they were in videoconference with instructors. They also promote wax carving practices, in case not everyone afford to acquire a micromotor (25).

Many schools use this period of paralysis to load the curriculum with academic activities that include online learning, in the hope that when returning students will spend more time in clinical practices. In the same way, the exams have moved to online formats, contrary to the ban that prevailed before to use this way of assessment (26).

A study was conducted at the Justus-Liebig University of Giessen's School of Dentistry, Germany, where $36.8 \%$ of students preferred face-to-face learning over online learning. Among the limitations of that study, students and instructors showed a predominantly positive attitude about the implementation of online learning, as it opens the door to use it beyond COVID-19 (27). 
In many institutions, online teaching was moved by sharing high-quality courses, clinical cases, and problem-based learning tutorials, through technological platforms and theoretical and practical exams designed to facilitate ending the academic year (28). In China, online teaching has delivered a wide range of solutions through telecommunications services, social software, interactive learning, learning, and virtual reality. The main form of online teaching in different schools included live broadcast $(74 \%)$, recorded broadcast $(68 \%)$, MOOCs $(50 \%)$, and video conferencing (45\%) (24). The use of virtual patients (VP) has also been implemented to develop skills such as the ability to interview patients, background checks, and treatment planning. Recently, in a randomized controlled clinical trial, computerized VPs were reported to be an effective alternative to small group discussions in terms of learning effectiveness (15). In another study conducted in China, various social programs and web platforms used in various dental schools were identified. Superstar Learning®, Rain Classroom®, Aula Tencent ${ }^{\circledR}$, and Pmphmooc $®$ were the most common software. In addition to these, DingTalk ${ }^{\circledR}$, Zoom Meeting ${ }^{\circledR}$, and Tencent Meeting® are also popular with different dental professors (24).

Multiple studies have shown that virtual reality improves the acquisition of manual skills in dentistry by offering tactile feedback, which allows students to virtually touch and feel dental tissue. However, a high investment is required by institutions to offer this type of technology (23). As well as virtual reality, the use of different types of software is proposed to carry out interactive activities, such as Kahoot ${ }^{\circledR}$, game design for students and interactive exams, among others. It is also possible to work on health promotion by disseminating educational material, such as videos and documents on social media. Another possibility is to make calls and send text messages to patients in the clinics using each institution's database (25). 
For the development of manual skills in the different specialties, it is possible to acquire or adapt training materials, such as dishwashing sponges, ox tongue, pig jaw, wax and soap sculptures, semi-adjustable articulator assemblies, molding, and manufacture of removable orthodontic appliances. All these activities are carried out with the remote supervision by the instructor (23). In a study conducted in New Zealand dental schools, regarding alternative teaching methods in case of suspension of clinical activities, students preferred online case-based discussions (26\%) and simulation clinical tasks (21\%). These schools' staff chose online tutorials (23\%) and casebased online discussions (23\%) as preferred alternative teaching methods (25).

Instructors cannot see each student's face during the entire online teaching time, so it is difficult to know if they really understand the content. Therefore, it is proposed to use interactive elements such as short questionnaires, random questions, frequent evaluations (telephone, text message, or email) with each student. They help stimulate students' enthusiasm for learning and help increase the effectiveness of online teaching (24). It is therefore inferred that students may need counseling and psychological support during and after the COVID-19 pandemic to minimize negative impacts of teaching and the development of their skills (23).

Dental practices carried out in dental simulation laboratories are considered one of the safest ways to acquire clinical skills and abilities without having to be physically in the clinical environment and in direct contact with patients. Since dental students must have excellent fine motor skills, as mentioned, simulation labs are ideal places to develop those skill. However, these practices sometimes create challenges, as in some countries time and resources are limited. As stated before, 
virtual reality with simulation technology offers dental schools and their students an excellent option, providing continuous feedback. In this way, they can improve manual and visual coordination, fine motor skills, and reflection skills $(14,15,29)$.

\section{Telemedicine}

To carry out an emergency dental treatment, the consultation should be carried out by telephone, the risks evaluated, and the necessary care provided (30). Telemedicine in dentistry has as its antecedent a term that was introduced in the past as "teledentistry." One will play a critical role by presenting two options at the time of retaking classes; one is the live interactive videoconference, and the other is the prerecorded conference which is based on the store-and-forward methodology (15). However, many dental schools/colleges began the virtualization process without prior preparation, due to the abrupt closure of universities (25). At the University of Pittsburgh in the United States, it was decided to suspend all patient chosen-based treatments. Even so, dental emergency cases were discussed in consultation by videoconference, until the Centers for Disease Control and Prevention (CDC) created a new action protocol (31). Similarly, at the University of Costa Rica, after weeks of research and planning, schools/colleges were able to continue with the theoretical courses using the virtual platform Metics®. They were complemented with didactic activities such as discussion of clinical cases, diagnosis, and treatment plans for virtual patients and interdisciplinary seminars with national and international speakers (15).

It should be noted that dentistry has undergone great technological innovations in the last decade. These innovations include the use of computers, digital imaging, digital modeling, digital planning and design, and the use of software for analysis and monitoring. These have been essential during 
the COVID-19 pandemic to continue teaching classes and be received by each of the students from home, without having to expose themselves in an environment prone to contagion by the virus (15).

\section{Biosecurity}

Due to the transmissibility that characterizes the virus, the high risk of exposure that exists during dental procedures is evident. Airborne microorganisms and bioaerosols generated during dental procedures by the use of handpieces, ultrasound, and triple syringes are the causes. The particles remain suspended in the environment contaminating the surfaces in the dental office. For this reason, the virus can be transmitted to dentists and patients $(3,13,31,32)$. In this regard, a reduction in the infectivity of the coronavirus has been reported due to exposure to disinfectants such as ethanol between $62 \%$ and $71 \%$, sodium hypochlorite $0.1 \%$ and $0.5 \%$, and glutaraldehyde to 3 $\%$, which have been shown to be effective in destroying certain microorganisms (16). As described above, it is clear that the control of bioaerosols constitutes the main challenge in dentistry to reduce the risk of transmission between students and patients (27).

The importance of exactly knowing the risk of infections in the dental office and correctly modeling the use of personal protective equipment has been highlighted. This, in order to invest sufficient financial resources and avoid exposing the dental team and patients to preventable risks (33). Given the great challenges facing dental education worldwide in the current pandemic, the CDC has delivered key recommendations for education and training in dental colleges/schools: 
1. Instructing and training all dental care personnel on infection prevention, specific to the job or task. This includes those who are employed by outside agencies and work at the center on contract and volunteers.

2. Training on principles applicable to both the safety of dental care personnel and the safety of patients.

3. Training during orientation and at regular intervals, for example, annually.

4. Maintaining records of training per state and federal requirements (34).

Iyer et al. mention that multiple trainings are being carried out for the health environment of the medical and dental areas, which are regulated by the American Dental Association (ADA) and the CDC to face the challenges presented in dental education programs with students, professors , cleaning staff, and patients. Therefore, daily updates are being carried out in these areas, due to the difficulty of implementing these procedures effectively (13,35-40). The spread of COVID-19 in Europe represented a challenge for both dental healthcare providers and dental schools/colleges. Dental regulatory authorities recommended that during the period of the pandemic outbreak, contact with patients be limited to emergencies and dental care emergencies and that strict safety measures be implemented (14).

Dental professionals must be prepared to face any impending challenges in clinical practice imposed by infectious diseases such as COVID-19. Patient care should include postponing consultations and quarantining patients at home or in health centers and hospitals. The role of the dentist in preventing and controlling viral infections must be constantly reviewed. Following the 
guidelines proposed by the WHO is important to prevent the action of SARS-CoV-2 in the population until medicines and vaccines are developed (37).

Dental students should receive information on the basic principles of epidemiology of infections, susceptibility, modes of transmission, risk factors, signs and symptoms of infection, laboratory diagnosis, preventive measures including precautions against droplets and air, eye protection, and health promotion. They also need to be instructed through lectures, demonstrations, and activities such as workshops, skits, and training camps, which can bring a new dimension to the education of students in infection control measures. (31).

The University of Sydney indicates that working in pairs in clinics is another useful measure to reduce aerosols. In this way, the who acts as dental assistant is only responsible for sucking the fluids, while the operator is in charge of the treatment. Likewise, it helps reduce treatment time. Therefore, the risk of dispersion of aerosol particles is lower. Protective barriers must be changed between patients by the student and their instructor. Protective lenses or masks should also be washed between patients, since it has been found masks keep the largest amount of organic waste at the end of treatments. Similarly, in Australia it was decided to limit the number of patients entering the waiting room to those with a physical disability or who do not have their own means of transportation. Those with their own vehicle must wait in their car until entering the facilities. In the same way, we must not forget that air conditioning systems in schools must be managed correctly because, through them, the virus can spread. This was the case in 2003 with SARS-COV1 in Hong-Kong. In 2020, in Wuhan, the virus was discovered in hospital air conditioning filters (27). 
A systematic review that included studies from Brazil, the United Kingdom, and France analyzed the compliance of educators and students in dental schools/colleges with hygiene procedures. They found that hand hygiene among dental students did not even reach $50 \%$ of students (31). A study conducted in Nigeria found that only half of clinical dentistry students had adequate general knowledge about COVID-19. They were not aware of updates on COVID-19, particularly a confirmed case, its definition, and the most common symptoms. The students, however, had a good perception and positive attitude towards infection control practices against COVID-19. Our recommendations are that the health authorities/institutions guidelines on COVID-19 are reviewed by the dental school/college authorities and included in school curricula. Governments should also make more PPTs available to clinical dentistry students (21). Dentists should look for specific care standards established by their state or country regarding the COVID-19 pandemic. Biosafety checklists should also be consulted to manage the protection of personal equipment, dental environments and devices, and surrounding spaces such as those used before, during, and after dental appointments. To achieve significant changes in clinical practice, dental schools and the general public must seek additional and rapid information to handle and improve this issue (35).

Additional precautionary measures suggested in a New Zealand study included the use of advanced grade personal protective equipment, increased surface disinfection, better ventilation, and the use of antimicrobial mouthwashes by patients prior to treatment. Ultimately, it was recommended to use personal protective equipment including face masks, gloves, gowns, glasses, hats, and face shields, in order to protect the skin and mucosa from contaminated secretions (16). Infection control education should be expanded into the dental curriculum. Similarly, students should be 
trained to properly protect themselves and prevent the infection from spreading even before they see their first patient. Online courses for basic infection control should be taken or smartphone applications developed that can keep students up-to-date with the latest information on infections, diseases, and preventive methods (31). A study in Saudi Arabia recommends developing effective strategies to improve dental practices and attitudes. The updating of preventive dentistry courses in dental schools and more hours of continuing education and workshops related to infection control can also be emphasized (15).

On the other hand, in the American continent, the Mexican government has implemented strategies at all levels to understand the behavior of the disease and be able to combat it. The Traffic Light System was created in which, by color, the type of dental care that can be carried out in all dental clinics in colleges/schools and in professional practice is indicated, depending on the severity of the pandemic, at a certain moment, in the different states of the country. The colors red and orange are assigned when there is a large number of COVID-19 cases and the situation is high risk; in such cases, the dentist can only attend emergencies. On the other hand, the yellow color indicates that care with the proper precautions is possible. Green represents normal attention (37) (figure 1). 
FIGURE 1

TRAFFIC LIGHT SYSTEM FOR DENTAL PRACTICE (CHART IN SPANISH)

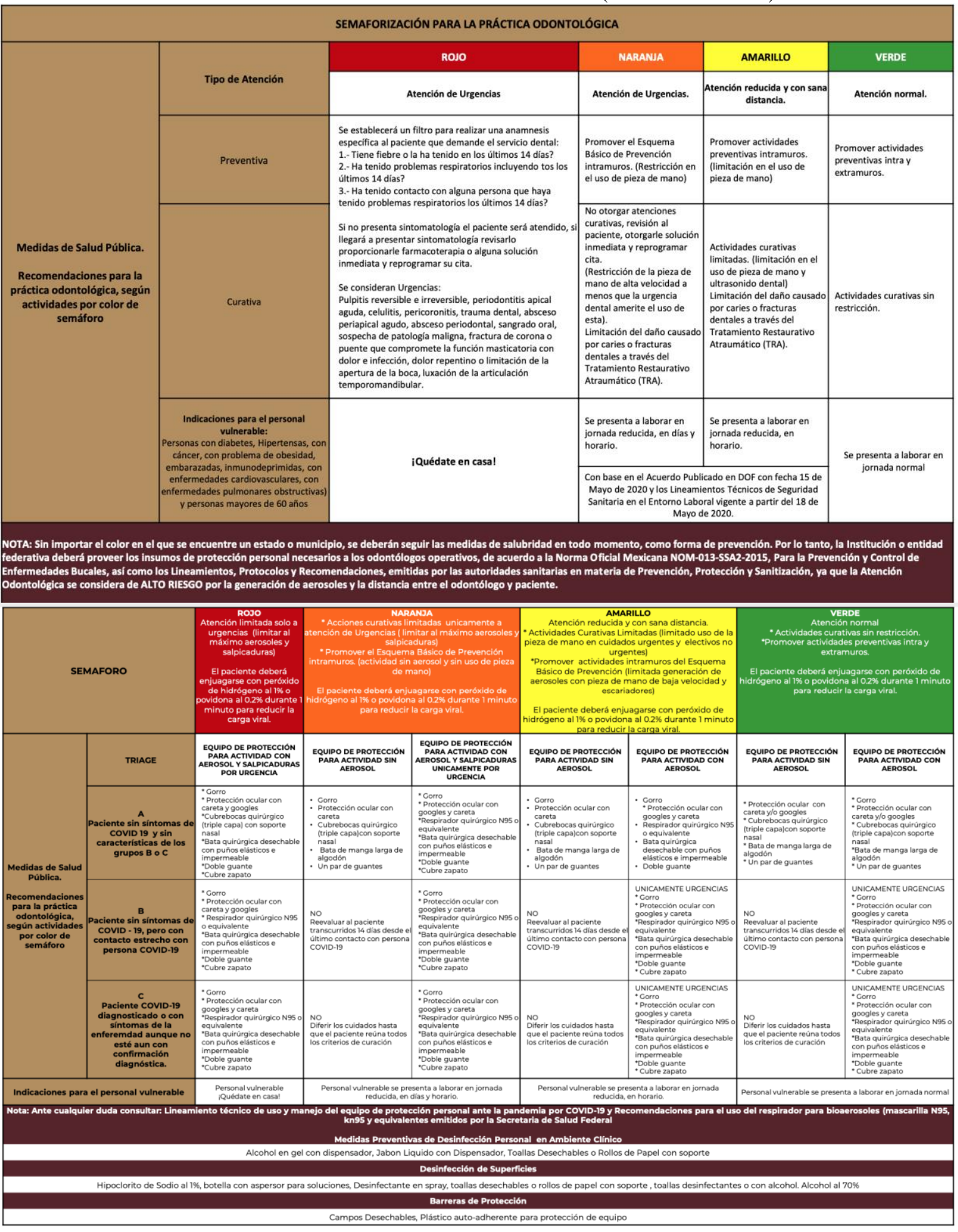


At the University of Monterrey in Mexico, a model of care was established in its two clinics at the School of Dentistry to deal with the pandemic. The purpose is to comply with biosecurity and avoid cross contamination between students, patients, instructors, and clinic staff, which should remain available for dental emergencies and postpone routine treatments. To comply with the prevention and control of oral diseases, as well as the operational strategies and control measures in public health that all dental personnel in Mexico must carry out, they based their guidelines by adjusting to the Official Mexican Standard No. $013(37,38)$. This is also due to the recent document entitled, “Agreement Establishing Specific Technical Guidelines for the Reopening of Economic Activities" of the Ministry of Health, an agency that identifies it as the "New Normal"" to achieve a safe and responsible return to work activities. The Ministry of Health, the Ministry of Labor and Economy, and the Mexican Institute of Social Security participated in this agreement in order to contemplate the level of health alert, as well as the infrastructure of the place and its characteristics. Finally, it is contemplated to develop specific guidelines on the promotion and protection of health of a mandatory nature (37). Schools/colleges of dentistry are required to comply with the guidelines and protocols established by the Mexican government. The University of Monterrey, in addition to complying with the above, established in its patient care protocols that, when entering the clinic, filling out a questionnaire on the risk of disease and taking the temperature. Patients who do not present symptoms and have a temperature lower than $37.3 \mathrm{oC}$ may be treated under all the biosafety measures established by NOM 013 and the CDC, that is, personal protective equipment for the dental student, instructor, and patient, maintaining two meters of distance in the waiting room, partial working time, air purifying lamps, six air changes per hour, four-hand work with absolute isolation on the patient and minimal use of high-speed part $(34,38,39)$. All areas should be disinfected after each patient. All students, instructors, patients, and staff of the school 
clinic must wear conventional clothing when leaving the facilities, as well as perform hand washing with the proper technique (39).

At the University of Campinas in Brazil, it was considered to reinforce the norms so that students, professors, and clinical staff use normal personal protective equipment, in addition to other protective equipment, such as disposable surgical gowns, respiratory masks (N95 and FFP2) or equivalent standard masks, goggles, and face shields regardless of the type of exam to be performed. In addition, they suggest that patients rinse their mouth with oxidizing agents such as $0.12 \%$ or $0.2 \%$ chlorhexidine or povidone-iodine before being treated (5). Also, in Brazil it has been chosen to carry out pre-consultations via telephone with patients to collect information on the signs and symptoms of COVID-19 that may have occurred in a period of 14 days before the appointment. Likewise, to avoid cross contamination, one instructor was assigned for every two students in the clinics to review their treatments and attend only one patient per student per day. This includes separating dental chairs with a minimum distance of 2 meters from each other and with mechanical barriers between them (32).

Manuals of biosafety standards have also been created that contain guidelines for adapting physical spaces, equipment, and behavior in school clinics to this new reality until the development of a vaccine (23). Finally, the European Union has signaled, around all these educational challenges, that it will continue to interact with its schools and members to collect relevant data, monitor the current situation, share evolving best practices, and communicate its findings to improve their preparedness and act in the best way against future pandemics (40). 


\section{DISCUSSION}

According to this review, on the challenges in dental teaching in universities that have originated as a result of the COVID-19 pandemic and that currently affects the entire world in the health, educational, economic, and social fields, it is evident that there is a number of studies, essays, opinion articles, and information in which various opinions are presented based mainly on empirical and theoretical studies regarding this pandemic. For this reason, this study was carried out to inform about this virus in relation to dentistry and the challenges it represents for dental education. What is found in published reviews that were reliable is highlighted and in which reviews with the following topics stand out. The first aspect that was reviewed was the educational tools. In the countries reviewed (Australia, New Zealand, the United States, Brazil, Mexico, Costa Rica, France, Germany, China, Nigeria, and Saudi Arabia, among others), digital platforms began to be used to teach classes, conduct webinars, and apply exams, to prevent students and instructors from being exposed to the virus. Online teaching has played an important role in education and has been an accepted strategy for higher education in the world and to which a good part of the students has shown a positive response $(21,24)$. However, there are exceptions, as shown by a study at the University of Giessen in which $36.8 \%$ of students preferred "face-to-face" learning (27).

It should be mentioned that, due to the current crisis, telemedicine has gained a relevant role when providing care to patients. Due to the total or partial closure of dental clinics in dental schools/colleges worldwide, in some countries the strategy of evaluating emergency cases through videoconference or telephone calls with patients was implemented $(30,15,31)$. This strategy turned out to be simple and practical to perform consultation without the need to expose the student in 
the clinics of their school/faculty. However, this strategy does not seem to be widely used in the dental field among different countries.

In relation to biosafety, it should not be forgotten that, since one of the main routes of transmission of the virus is the dispersion of bioaerosols, its control will be the main challenge in dentistry. Much of the clinical procedures involve the use of rotating and vibrating instruments such as handpieces, ultrasound, and triple syringes, which generate a certain number of particles in bioaerosols that disperse in the environment, adhering to nearby surfaces (3). Therefore, the control of bioaerosols helps reduce the risk of contagion between students and patients $(16,27)$. Therefore, it is important that academics and students at dental colleges/schools stay informed regarding the relevant regulations on biosafety protocols that public health authorities dictate in each country or locality, as well as global organizations such as the ADA and the CDC $(35,13,35)$. In Europe, as well as in several countries in the American continent, the measure was taken to suspend classes and clinical care to protect students and instructors. However, over time, the dental regulatory authorities provided instructions and recommendations aimed at limiting contact with patients to dental emergencies only and implementing strict safety measures to ensure prevention of cross infection $(14,27,37)$.

In Australia, in the same way, some biosecurity measures were implemented to provide safer care. They established pair work in the clinics and limited the number of patients entering waiting rooms to those with physical disabilities or who do not have a personal vehicle (27). In Brazil, the precaution was taken to separate dental chairs with a minimum distance of 2 meters, as well as to install mechanical barriers between them and, in order to avoid cross contamination, only one instructor was 
assigned for every two students to the clinics ( 32). In this same sense, Mexico created a Traffic Light System in which, by color, the type of dental care that could be provided in dental clinics in colleges/schools and in professional practice that depends on the severity of the pandemic in certain moment in the different states of the country (37).

Likewise, in several countries such as Saudi Arabia and Mexico, the importance of promoting preventive dentistry courses in dental schools/colleges has been emphasized. Thus, students and instructors, by being prepared and receiving constant updates on prevention and public health, are better prepared to face situations such as the current pandemic. They will be able to act faster in the face of the situation and avoid a crash later due to misinformation (15,37-40).

\section{CONCLUSIONS}

This review analyzes and synthesizes relevant information and makes it available to students and academics in the context of dental teaching. It describes educational, biosafety, and health regulations strategies, which have been developed in response to the disruption generated in the teaching and dental care processes by COVID-19.

It is necessary to consider the restructuring of educational programs so that dental practices are safer, more efficient and effective, increasing knowledge in public health so that students and dental professionals are prepared in this field for any type of health emergency. 
It will be decisive that the colleges/schools of dentistry in Mexico and other countries adhere to the indications of government health agencies, referring to epidemiological traffic lights (behavior of the disease in each state) for the care of dental patients, complying with the provisions legal, regulatory and health regulations. Models like this can be used in other regions of the planet.

It is the responsibility of all students and dentists in the different areas of dental schools/colleges and public and private health centers and clinics to acquire and develop competencies and skills for health control and promotion. These skills and competencies must be based on valid and updated knowledge in public health, depending on the country in which students/dentists reside, in order to minimize the probability of contagion of this virus in the population.

This review is a valuable tool for students and dentists who seek to know teaching strategies currently applied and developed globally to face this pandemic.

\section{RECOMMENDATIONS}

Dental care presents a high risk of contagion from COVID-19. Our profession is the highest risk, so it is recommended to carry out clinical practice in schools/colleges of dentistry and private and public health services according to current regulations.

An undergraduate (predoctoral) and postgraduate (postdoctoral) dental student should continue their studies in educational institutions adhering to biosafety guidelines. 
Adapt and adjust teaching and learning methods and strategies to the changing and disruptive conditions of the environment.

Update and prepare study plans in dental schools/colleges to face the current COVID-19 pandemic and other similar ones that may arise.

Emphasize preventive dentistry courses and increase the number of hours dedicated to continuing education in infection control.

\section{ACKNOWLEDGEMENTS}

To the Nuevo León State Oral Health Coordination, Mexico, for their valuable support in obtaining information.

\section{REFERENCES}

1. Meng L, Hua F, Bian Z. Coronavirus disease 2019 (COVID-19): emerging and future challenges for dental and oral medicine. J Dent Res. 2020; 99(5): 481487. https://doi.org/10.1177/0022034520914246

2. Organización Mundial de la Salud (OMS). Brote de enfermedad por coronavirus (COVID-19): orientaciones para el público. Washington, DC: OMS; 2020. https://www.who.int/es/emergencies/diseases/novel-coronavirus-2019 
3. Peng X, Xu X, Li, Y, Cheng L, Zhou X, Ren B. Transmission routes of 2019-nCoV and controls in dental practice. Int J Oral Sci. 2020 Mar 3; 12(1): 9. https://doi.org/10.1038/s41368$\underline{020-0075-9}$

4. Volgenant CMC, Persoon IF, de Ruijter RAG, de Soet JJH. Infection control in dental health care during and after the SARS-CoV-2 outbreak. Oral Dis. 2020; https://doi.org/10.1111/odi.13408

5. Baghizadeh Fini M. What dentists need to know about COVID-19. Oral Oncol. 2020 Jun; 105:104741. https://doi.org/10.1016/j.oraloncology.2020.104741

6. Fontenele RC, Gomes AF, Freitas DQ. Oral radiology practice in dental schools during the COVID-19 pandemic: What will be the new normal? Imaging Sci Dent. 2020 Sep; 50(3): 265267. https://doi.org/10.5624/isd.2020.50.3.265

7. Arher A, Patel B, Ruparel NB, Diogenes A, Hargreaves KM. Coronavirus disease 19 (COVID19): implications for clinical dental care. J Endod. 2020; 46(5): 584-595. https://doi.org/10.1016/j.joen.2020.03.008

8. Odeh ND, Babkair H, Abu-Hammad S, Borzangy S, Abu-Hammad A, Abu-Hammad O. COVID-19: Present and future challenges for dental practice. Int J Environ Res Public Health. 2020 Apr 30; 17(9): 3151. https://doi.org/10.3390/ijerph17093151

9. Izzetti R, Nisi M, Gabriele M, Graziani F. COVID-19 Transmission in dental practice: brief review of preventive measures in Italy. J Dent Res. 2020 Aug; 99(9): 1030-1038. https://doi.org/10.1177/0022034520920580

10. Desai B. Clinical implications of the COVID-19 pandemic on dental education. J Dent Educ. 2020; 84(5): 512. https://doi.org/10.1002/jdd.12162 
11. Norina F. COVID-19 challenges in dental health care and dental schools. Rom J Oral Rehab. 2020; 12(2) 6-12.

12. Farooq I, Ali S, Moheet IA, AlHumaid J. COVID-19 outbreak, disruption of dental education, and the role of teledentistry. Pak J Med Sci. 2020 Nov-Dec; 36(7): 1726-1731. https://doi.org/10.12669/pjms.36.7.3125

13. Loch C, Kuan IBJ, Elsalem L, Schwass D, Brunton PA, Jum'ah A. COVID-19 and dental clinical practice: Students and clinical staff perceptions of health risks and educational impact. J Dent Educ. 2020; 1-9. https://doi.org/10.1002/jdd.12402

14. Hung M, Licari FW, Hon ES, et al. In an era of uncertainty: Impact of COVID-19 on dental education. J Dent Educ. 2020;1-9. https://doi.org/10.1002/jdd.12404

15. Alzahrani AAH. Practices and attitudes of dental practitioners toward patient management during the COVID-19 pandemic in Saudi Arabia. J Res Med Dent Sci., 2020; 8(3): 214-223.

16. Dos Santos M, Ribeiro N, Dos Santos V, Oliveira C. Doença por Coronavírus 2019: desafios emergentes e o ensino odontológico brasileiro. Rev Da Abeno. 2020; 20(2): 2-15.

17. Umeizudike KA, Isiekwe IG, Fadeju AD, Akinboboye BO, Aladenika ET. Nigerian undergraduate dental students' knowledge, perception, and attitude to COVID-19 and infection control practices. J Dent Educ. 2020; 1-10.

18. Whittemore R, Chao A, Jang M, Minges KE, Park C. Methods for knowledge synthesis: an overview. Heart Lung. 2014; 43(5): 453-461. https://doi.org/10.1016/j.hrtlng.2014.05.014.

19. Veesaci MB. CDC reminds clinicians to use standard precautions, recommends isolating patients with coronavirus symptoms. Chicago, IL: American Dental Association; 2020 Feb. 7. 
20. Akinkugbe AA, Garcia DT, Smith CS, Brickhouse TH, Mosavel M. A descriptive pilot study of the immediate impacts of COVID-19 on dental and dental hygiene students' readiness and wellness. J Dent Educ. 2020; 1-10. https://doi.org/10.1002/jdd.12456

21. Wang K, Zhang L, Ye L. A nationwide survey of online teaching strategies in dental education in China. J Dent Educ. 2020; 1(7). https://doi.org/10.1002/jdd.12413

22. Cassol J, Coelho C, Andreade J. The impacts of the COVID-19 pandemic on the teaching of dentistry in Brazil. J Dent Educ. 2020; 84(11): 1185-1187. https://doi.org/10.1002/jdd.12364

23. Chavarría D, Gómez A, Dittel C, Montero M. E-learning in dental schools in the times of COVID-19: A review and analysis of an educational resource in times of the COVID-19 pandemic. Odovtos-Int J Dent Sci. 2020; 22(3): 69-86. https://doi.org/10.15517/ijds.

24. Damien NM, Chappell DJ, van der Hoeven R. Teaching emergency medicine in a dental school during the time of COVID-19. J Dent Educ. 2020; 1-3. https://doi.org/10.1002/jdd.12322

25. Sukumar S, Dracopoulos SA, Martin FE. Dental education in the time of SARS-CoV-2. Eur J Dent Educ. 2020; 1-7. https://doi.org/10.1111/eje.12608

26. Quinn B, Field J, Gorter R, Akota I, Manzanares MC, Paganelli C, Davies J, Dixon J, Gabor G, Amaral Mendes R, Hahn P, Vital S, O'Brien J, Murphy D, Tubert-Jeannin S. COVID-19: The immediate response of European academic dental institutions and future implications for dental education. Eur J Dent Educ. 2020; 24(4): 811-814. https://doi.org/10.1111/eje.12542

27. Schlenz MA, Schmidt A, Wöstmann B, Krämer N, Schulz N. Students' and lecturers' perspective on the implementation of online learning in dental education due to SARS-CoV-2 (COVID-19): a cross-sectional study. BMC Med Educ. 2020; 20(354): 2-7. https://doi.org/10.1186/s12909-020-02266-3 
28. Ferrazzano G, Ingenito A, Cantile T. COVID-19 disease in children: what dentists should know and do to prevent viral spread. the Italian point of view. Int J Environ Res Public Health. 2020; 17(10): 3642. https://doi.org/10.3390/ijerph17103642

29. Barabari P, Moharamzadeh K. Novel coronavirus (COVID-19) and dentistry-a comprehensive review of literature. Dent J (Basel). 2020 May 21; 8(2): 53. https://doi.org/10.3390/dj8020053

30. Ghai S. Are dental schools adequately preparing dental students to face outbreaks of infectious diseases such as COVID-19? J Dent Educ. 2020; (84): 631-633. https://doi.org/10.1002/jdd.12174

31. Peres KG, Reher P, de Castro RD, Vieira AR. COVID-19-related challenges in dental education: experiences from Brazil, the USA, and Australia. Pesqui Bras Odontopediatria Clín Integr. 2020; 20(supl 1): 1-10. https://doi.org/10.1590/pboci.2020.130

32. Xu R, Cui B, Duan X, Zhang P, Zhou X, Yuan Q. Saliva: potential diagnostic value and transmission of 2019-nCoV. Int Oral Sci. 2020; 12(1): 11. https://doi.org/10.1038/s41368-020$\underline{0080-\mathrm{Z}}$

33. Bizzoca ME, Campisi G, Lo Muzio L. Covid-19 pandemic: what changes for dentists and oral medicine experts? A narrative review and novel approaches to infection containment. Int J Environ Res Public Health. 2020; 17(11): 3793. https://doi.org/10.3390/ijerph17113793

34. Centros para el Control y la Prevención de Enfermedades (CDC). Resumen de las "Prácticas para la prevención de enfermedades en entornos odontológicos: Expectativas básicas para la atención segura". Atlanta, GA: Departamento de Salud y Servicios Humanos de los Estados Unidos, CDC, Centro Nacional para la Prevención de Enfermedades Crónicas y Promoción de la Salud, División de Salud Oral; 2017 Mar. 
35. Sigua-Rodríguez EA, Bernal-Pérez JL, Lanata-Flores AG, Sánchez-Romero C, RodriguezChessa J, Haidar ZS, Olate S, Iwaki-Filho L. COVID-19 y la Odontología: una revisión de las recomendaciones y perspectivas para Latinoamérica. Int J Odontostomat. 2020; 14(3): 299309.

36. De Vasconcelos GB, Borges S, Borges RE, Calderon P. COVID-19: Perspectives for the management of dental care and education. J Appl Oral Sci. 2020; 28.

37. Estados Unidos Mexicanos, Secretaría de Gobernación. Acuerdo por el que se establecen los lineamientos técnicos específicos para la reapertura de las actividades económicas. Diario Oficial. 2020 May. 29.

38. Estados Unidos Mexicanos, Secretaría de Salud. Norma oficial mexicana para la prevención y control de enfermedades bucales. NOM-013-SSA2-2015. Ciudad de México: la Secretaría; 2016 Nov. 23.

39. Medina ASJ, Salinas NA. Lineamientos de bioseguridad utilizados en las clínicas dentales periféricas de la Universidad de Monterrey durante la pandemia de COVID-19. Rev ADM. 2020; 77(3): 146-152. https://doi.org/10.35366/94008

40. Iyer P, Aziz K, Ojcius D. Impact of COVID-19 on dental education in the United States. J Dent Educ. 2020; 84(6): 718-722. https://doi.org/10.1002/jdd.12163 